\title{
PLCG2 wt Allele
}

National Cancer Institute

\section{Source}

National Cancer Institute. PLCG2 wt Allele. NCI Thesaurus. Code C49383.

Human PLCG2 wild-type allele is located within the vicinity of 16q24.1 and is approximately $179 \mathrm{~kb}$ in length. This allele, which encodes 1-phosphatidylinositol-4,5bisphosphate phosphodiesterase gamma 2 protein, plays a role in the hydrolysis of 1 phosphatidylinositol-4,5-biphosphate. This results in the production of specific second messengers involved in signal transduction. 